\title{
Night Clubs
}

As in all large cities, the quality of Los Angeles after-dark entertainment varies. There is the honky-tonk area of Main Street and East Fifth Street, where semi-nude "B-girls" have brought Los Angeles nationwide notoriety by way of national magazine articles. There is also the fabulously chic Sunset Strip and Hollywood area, even more widely publicized.

These are the extremes, and most visitors will find a peek at both interesting. However, the heavy volume of Los Angeles night life pours through the relatively insignificant neighborhood bars, cocktail lounges, dine-and-dance establishments. Hundreds of thousands of Angelenos are acquainted with neither Main Street nor The Strip.

Following is a list, alphabetically arranged, of a few of the more widely-known clubs. Policies and times of events are those in effect in the Fall of 1940, and are of course subject to change.

\section{DOWNTOWN}

Biltmore Bowl, Biltmore Hotel, 515 S. Olive St. Dinner from 7:30 p.m.; no couvert. Orchestra; dancing. Two floor revues nightly. Bar. Much frequented by "visiting firemen" and the football crowd during the season.

Cafe Casino, 425 S. Main St. Prices reasonable. You can use your own judgment where to stop. Very ripe entertainment. Oldtime burlesque with seminude girls.

Paris Inn, 210 East Market St. Dinner from 5:30 p.m. Orchestra. Dancing. Floor shows 8 p.m. and I I p.m. Separate bar. A rather unusual bar and singing waiters. Closed Sundays.

\section{WILSHIRE DISTRICT}

Cocoanut Grove, Ambassador Hotel, 3400 Wilshire Blvd. Dinner from 7 p.m.; couvert charge. Orchestra; dancing. Floor show il p.m. Bar. Very popular; consistently good entertainment. 
xlviii N I G H T C L U B S

Town House, 639 S. Commonwealth Ave. The Zebra Room is frequented by the young set.. A more conservative atmosphere in the Wedgewood Room.

Wilshire Bowl, Inc., 5665 Wilshire Blvd. Dinner 6 p.m. to 2 a.m., no couvert.

\section{HOLLYWOOD}

Beachcomber Cafe, 1727 N. McCadden Pl. Prices are slightly stiff. Specializes in Oriental food and drinks. Frequented by the many lesser Hollywood actors.

Earl Carroll's Theater-Restaurant, 6230 Sunset Blyd. Dinner from 7:30 to I I p.m., no couvert; without dinner, admission charge. Two acts with 30 principals and 6o-girl revue. Shows, 9 and 12 p.m. For those who like girl shows and revolving stages.

Florentine Gardens, 5955 Hollywood Blvd. Dinner from 6:30 p.m., no couvert. Without dinner, a small admission charge. Orchestra. Dancing. Cocktail lounge. Three floor shows nightly. Girl revues. Situated in the heart of Hollywood.

Grace Hayes Lodge, I I 345 Ventura Blvd. (north of town). Dinner, no couvert. Minimum charge. A gay informality. Celebs, if in the mood, usually put on impromptu acts-quality varies.

"It" Cafe, I637 N. Vine St. Dinner 5 to 10 p.m. Supper 10 p.m. to 2 a.m. No couvert. Dancing. No floor show. Bar.

La Conga Club, Inc., I551 N. Vine St. Dinner from 7 p.m. No couvert. Two orchestras; two revolving orchestra stages; continuous dancing. No floor show. Bar.

Slapsy Maxie Rosenbloom's Cafe, 7165 Beverly Blvd. Dinner from 6 p.m. No couvert. Orchestra, but no dancing by patrons. Three or four funny floor shows nightly, with Deadpan Maxie in the middle of things.

Seven Seas Cafe, 6904 Hollywood Blvd. Dinner from 6 p.m. No couvert. Hawaiian orchestra and entertainers, dressed in native costumes. Floor shows II and 12 p.m. and 2 a.m. Bar. Dancing from 8:30 p.m. Hawaiian Island atmosphere, complete with "rain on the roof." 


\section{BEVERLY HILLS AND THE SUNSET STRIP}

Bali Restaurant, 8804 Sunset Blvd. Dinner; no couvert, no minimum. Atmosphere in keeping with the name. Light, risque entertainment. East Indian curry a specialty.

Beverly-Wilshire, 9514 Wilshire Blvd. Dinner. Separate bar. Dancing.

Cafe LaMaze, 9039 Sunset Blvd. Dinner. Dancing to name-bands. Special entertainment. Separate bar.

Ciro's, 8433 Sunset Blvd. Dinner 7 to Io p.m.; couvert charge. Orchestra. Dancing to 2 a.m. A favorite spot with movie folks. Patrons are requested to dress formally on Saturday. Somewhat expensive.

Victor Hugo. (See Restaurants.)

\section{SOUTHGATE}

Topsy's Cafe, 2800 Firestone Blvd. Dinner from 6 p.m. No couvert. Floor shows, 9:30 p.m. and 12:30 a.m. Bar. Orchestra. Dancing. Closed Mon. 
This page intentionally left blank 